\title{
Genistein affects the morphology of pituitary ACTH cells and decreases circulating levels of ACTH and corticosterone in middle-aged male rats
}

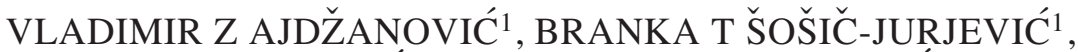 \\ BRANKO R FILIPOVIĆ ${ }^{1}$, SVETLANA L TRIFUNOVIĆ ${ }^{1}$, DEJAN D BRKIC ${ }^{2}$, \\ MILKA I SEKULIĆ ${ }^{1}$ and VERICA LJ MILOSEVIĆ ${ }^{1}$
}

\author{
${ }^{1}$ Department of Cytology, Institute for Biological Research "Siniša Stankovićc", 11060 Belgrade, Serbia; \\ ${ }^{2}$ Johnson \& Johnson S.E. Inc., Belgrade 11060, Serbia
}

\begin{abstract}
The soybean phytoestrogen, genistein, is increasingly consumed as an alternative therapeutic for age-related diseases, namely cardiovascular conditions, cancer and osteoporosis. However, despite the beneficial effects on health, concern has been raised that this isoflavone also acts as an endocrine-disrupting chemical. The aim of this study was to examine the effects of genistein on immunohistomorphometric features of pituitary adrenocorticotropic cells (ACTH) and blood concentrations of ACTH and corticosterone in orchidectomized middle-aged male rats. Sixteen-month-old Wistar rats were divided into sham-operated (SO), orchidectomized (Orx) and genistein-treated orchidectomized (Orx+G) groups. Genistein $(30 \mathrm{mg} / \mathrm{kg} / \mathrm{day})$ was administered subcutaneously for three weeks, while the control groups received the vehicle alone. ACTH cells were identified by the peroxidase-antiperoxidase (PAP) immunohistochemical procedure. Circulating concentrations of ACTH and corticosterone were measured by immunoassay. Orchidectomy reduced $(\mathrm{p}<0.05)$ the cell volume and the relative volume of ACTH cells in comparison to SO rats. Genistein treatment further decreased $(\mathrm{p}<0.05)$ these morphometric parameters and reduced $(\mathrm{p}<0.05)$ circulating ACTH and corticosterone concentrations by more than $20 \%$ in comparison to both Orx and SO rats. In conclusion, genistein modulated the immunohistomorphometric features of ACTH cells and decreased blood ACTH and corticosterone levels, which supports evidence that this isoflavone affects the hypothalamic-pituitary-adrenal axis and suppresses glucocorticoid hormone secretion.
\end{abstract}

Key terms: ACTH cells, corticosterone, genistein, middle-age, orchidectomy, rats

\section{INTRODUCTION}

Andropause is an age-related partial decline of serum testosterone that is usually accompanied by decreases of other hormones, namely dehydroepiandrosterone, growth hormone, thyroid hormones and melatonin (Lamberts et al., 1997). During this period of life the frequency of cardiovascular diseases, cancer, osteoporosis, as well as stress-related psychiatric disorders, depression, irritability and sleep disturbance, increases (Vance, 2003). Augmented activity of the hypothalamic-pituitary-adrenal (HPA) axis is associated with a high incidence of stress-related psychiatric disorders with advancing age (Hatzinger et al., 2000).

The soybean isoflavone, genistein, is structurally similar to estradiol $17 \beta$ (Price and Fenwick, 1985; Setchell, 1998). It competes with a lower potency for binding to endogenous estrogen receptors (ERs) and exerts significantly higher affinity for ER $\beta$ than for ER $\alpha$ (Kuiper et al., 1997). In addition to this mild estrogenic/ antiestrogenic effect, genistein has strong antioxidative potency (Benassayag et al.,

Corresponding author: Vladimir Ajdžanović, Institute for Biological Research "Siniša Stanković", Despota Stefana Boulevard 142, 11060 Belgrade, Serbia, Tel.: +381-11-2078-320; Fax:+381-11-2761-433, E-mail adress: avlada@ibiss.bg.ac.yu 
2002) and inhibited activity of the tyrosine kinase enzyme family (Akiyama et al., 1987). These mechanisms certainly contribute to its putative beneficial effects in the prevention and treatment of cancer, cardiovascular and other age-related diseases (Ramos, 2007). Combining genistein with radiation is a potentially important novel strategy for the treatment of prostate cancer (Raffoul et al., 2006). Consumption of high doses of purified isoflavones from soybean in the form of nutritional supplements has become very popular among the Western population in recent years. However, there is a growing concern that phytohormones also act as endocrine disruptive chemicals, which interfere with the function of different endocrine systems (Brevini et al. 2005; Caserta et al. 2008; Phillips and Tanphaichitr, 2008).

Estrogen treatment has been shown to decrease the level of proopiomelanocortin (POMC) mRNA, a precursor of the ACTH molecule, and lowered the ACTH response in stress-stimulated ovariectomized adult female rats (Redei et al., 1994). Studies concerning the potential effects of the phytoestrogen, genistein, on the function of the HPA axis are rather limited. Based on the findings that some cytokines, namely IL-1, IL-2 and IL-6, are important stimulators of pituitary ACTH secretion (Bateman et al., 1989; Besedowsky and del Ray, 1996), in vitro studies (Katahira et al., 1998) demonstrated a suppressive effect of genistein on cytokine-mediated stimulation of expression of the POMC gene. However, chronic treatment of weanling rats with genistein at $40 \mathrm{mg} / \mathrm{kg}$ significantly reduced serum corticosterone concentration and elevated ACTH level by a feedback mechanism (Ohno et al., 2003).

Considering the available literature data the authors assumed that ACTH cell morphology can change after genistein treatment (hypothesis behind the aim) and their idea was to investigate how it can change, i.e. to make a certain step in this field, with available methodology. The precise aim of our study was to examine the effects of subcutaneous treatment with therapeutic doses of the soybean isoflavone, genistein, on immunohistomorphometric features of ACTH cells, ACTH hormone secretion and consequently glucocorticoid hormone synthesis in orchidectomized middle-aged male rats, which is an animal model of the andropause.

\section{MATERIALS AND METHODS}

\section{Animals and diets}

The experiments were performed on 16month-old male Wistar rats. They were bred in the Institute for Biological Research, Belgrade, Serbia, housed two per cage, exposed to a 12-12 h light-dark cycle and kept at $22 \pm 2{ }^{\circ} \mathrm{C}$. Two weeks before the experiment, the rats started to eat a soy-free diet (according to Picherit et al., 2000) prepared in cooperation with the Department of Nutrition, School of Veterinary Medicine, Belgrade, Serbia, and INSHRA PKB, Belgrade, Serbia, with corn oil as a fat source.

The diet contained per $100 \mathrm{~g}$ : $20.3 \mathrm{~g}$ casein; 65 g carbohydrate (45 g cornstarch +20 g sucrose); $5.2 \mathrm{~g}$ corn oil; $3.7 \mathrm{~g}$ fiber (crystalline cellulose); $1.5 \mathrm{~g}$ vitamin/ mineral mix (Ca-phosphate deficient); $1.8 \mathrm{~g}$ dibasic calcium phosphate; $1 \mathrm{~g}$ calcium carbonate; $1.5 \mathrm{~g}$ DL-methionine. Casein and crystal cellulose originated from Alfa Aesar, Johnson Matthey Gmbh \& Co.KG, Karlsruhe, Germany; carbohydrate, oil, vitamin/mineral mix, calcium carbonate, calcium phosphate from INSHRA PKB, Belgrade, Serbia; and DL-methionine from Sigma Chemical Company, St. Louis, MO, USA. Food and water were available ad libitum.

\section{Experimental design}

Sham surgery and orchidectomy were performed under ketamine anaesthesia (Ketamine hydrochloride; Richter Pharma, Wels, Austria; 15 mg/kg b.w.). Shamoperated (SO; $n=8)$ and orchidectomized rats were allowed to recover for 2 weeks. After recovery, the orchidectomized rats were divided into two groups of eight animals each. One group was 
subcutaneously treated with genistein (Nutraceutica, Monterenzio, Italy; Orx+G) in a dose of $30 \mathrm{mg} / \mathrm{kg} \mathrm{b}$.w. every day except on Sundays for 3 weeks. Genistein was predissolved in a minimal volume of absolute ethanol $(0.17 \mathrm{ml})$ and mixed with sterile olive oil $(0.33 \mathrm{ml})$. The final volume of mixture injected was $0.5 \mathrm{ml}$ per animal. The other orchidectomized group (Orx) and the SO group were given the same volume $(0.5 \mathrm{ml})$ of vehicle alone. All animals were killed by decapitation $24 \mathrm{~h}$ after the last injection.

The experimental protocols were approved by the Animal Care Committee of the Institute for Biological Research (Belgrade, Serbia) in conformity with the recommendation provided in the Guide for the Care and Use of Laboratory Animals (1996, National Academy Press, Washington D.C.).

\section{Immunohistochemical studies}

Pituitary glands were excised, weighed, fixed in Bouin's solution for $48 \mathrm{~h}$ and embedded in paraplast. The relative pituitary weights were calculated from the ratio of the measured pituitary weight and the body weight for each animal.

ACTH-producing cells were identified by immunohistochemistry using the peroxidase-antiperoxidase method (PAP; described by Sternberger et al., 1970). Endogenous peroxidase activity was first blocked by incubation with $0.3 \%$ hydrogen peroxide in methanol for 15 min. Reduction of non-specific background staining was achieved by incubation with normal porcine serum (DAKO A/S, Glostrup, Denmark), diluted in phosphate-buffered saline $\mathrm{pH} 7.4$ (PBS; 1:10), for $45 \mathrm{~min}$. Sections were then overlaid with commercially diluted primary antibodies (hACTH antiserum DAKO A/S, Glostrup, Denmark) for $24 \mathrm{~h}$ at $4^{\circ} \mathrm{C}$. This antibody strongly cross-reacts with rat ACTH (Starčević et al., 2000; verified by Dr B.A. Yang of Dako Corp.). After washing in PBS for $5 \mathrm{~min}$, sections were incubated for 60 min with a second antibody, swine anti-rabbit IgG (DAKO, Glostrup, Denmark; diluted 1:100 in PBS), rinsed again in PBS for $5 \mathrm{~min}$ and then incubated with rabbit PAP complex (DAKO $\mathrm{A} / \mathrm{S}$, Glostrup, Denmark; diluted 1:100 in PBS), for $45 \mathrm{~min}$. Binding sites were visualised using $0.05 \%$ diaminobenzidine (DAB; Serva, Heidelberg, Germany) and $0.03 \%$ hydrogen peroxide in $0.2 \mathrm{M}$ TRIS$\mathrm{HCl}$ buffer, $\mathrm{pH}$ 7.4. The sections were counterstained with hematoxylin and mounted in Canada balsam (Molar Chemicals KFT, Budapest, Hungary). For the control sections, the primary antibody was omitted and replaced by PBS, pH 7.4.

\section{Morphometry}

Rat pituitaries were serially cut to $5 \mu \mathrm{m}$ thick sections. Two sections from the dorsal, three from the middle and two from the ventral part (totally seven sections, $200 \mu \mathrm{m}$ apart) of the rat pituitary glands were analyzed. The point counting method was used at total magnification of $\mathrm{x} 1000$ (Weibel, 1979). $\mathrm{M}_{42}$ multipurpose test grid, inserted into the ocular of a Zeiss light microscope (Jena, Germany), was randomly positioned on the pituitary section at the beginning of counting. Counting was carried out on the following 50 test fields per section. Average values were calculated per pituitary i.e. per animal (7 sections, 350 test fields) and five pituitaries were analysed per group. Cell volume $\left(\mathrm{Vc}, \mu \mathrm{m}^{3}\right)$, volume of the nuclei $\left(\mathrm{Vn} ; \mu \mathrm{m}^{3}\right)$ and volume density (percentage of immunoreactive cells in $\left.\mu \mathrm{m}^{3}, \mathrm{~V}_{\mathrm{VC}} ; \%\right)$ were determined for ACTH-immunoreactive cells.

The following parameters were counted: Pn-number of points hitting on nuclei of immunohistochemically labelled cells inside the test field, Ptc-number of points hitting on cytoplasm of immunohistochemically labelled cells inside the test field, Nn-number of immunohistochemically labelled cell nuclei inside the test field, Formula for the nuclei volume calculation was:

$$
\mathrm{Vn}=\mathrm{V}_{\mathrm{Vn}} / \mathrm{N}_{\mathrm{V}}
$$

and formula for the cell volume calculation was:

$$
\mathrm{Vc}=1 / \mathrm{N}_{\mathrm{V}} \text {, considering }
$$


$\mathrm{V}_{\mathrm{Vn}}$ - volume density of ACTH cell nuclei and $\mathrm{N}_{\mathrm{V}}$ - numerical density of ACTH cells. Nuclei volume density $\left(\mathrm{V}_{\mathrm{Vn}_{\mathrm{n}}}\right)$ provides information about nuclei attendance in estimated cells and is calculated using the formula:

$$
\mathrm{V}_{\mathrm{Vn}}=\sum \mathrm{Pn} / \sum \mathrm{Ptc}
$$

Since rat ACTH cells are mononuclear, the $\mathrm{N}_{\mathrm{V}}$ corresponded to the number of cells per cubic milimeter, according to the formula:

$$
\mathrm{N}_{\mathrm{V}}=(\mathrm{k} / \beta)\left(\mathrm{N}_{\mathrm{A}}^{3 / 2} / \mathrm{V}_{\mathrm{Vn}}{ }^{1 / 2}\right)
$$

On the basis of earlier karyometric studies (Malendowicz, 1974), the shape coefficient $\beta$ for pituitary cells was estimated to be $1.382, \mathrm{k}$ is factor related to cell distribution according to their size (in case of ACTH cells its value is 1) and $\mathrm{N}_{\mathrm{A}}$ is number of cells in the plane of pituitary tissue section. $\mathrm{N}_{\mathrm{A}}$ is calculated using the formula:

$$
\mathrm{N}_{\mathrm{A}}=\sum \mathrm{Nn} / \sum \mathrm{Ptc} \cdot \mathrm{a},
$$

where a represents the rhomb area that belongs to every point of the test system and is calculated using the formula:

$$
a=d^{2} 3^{1 / 2} / 2 \text {, considering }
$$

$\mathrm{d}$, the test line length in the used test system.

Volume density $\left(\mathrm{V}_{\mathrm{VC}}\right)$ is calculated as a ratio of Pn and Ptc sum (Pn+Ptc) and total number of points in test system. Considering the fact that test system with 42 points was used and parameters were calculated using 50 test fields, the definite formula was:

$$
\mathrm{V}_{\mathrm{VC}}=(\mathrm{Pn}+\mathrm{Ptc}) / 50 \cdot 42
$$

\section{Biochemical analyses}

Blood was collected from the trunk and separated plasma and sera samples of all animals were stored at the same time at $70^{\circ} \mathrm{C}$ until assayed. Plasma levels of ACTH were determined without diluting the plasma, by the IMMULITE method (DPC, Los Angeles, USA), in duplicate samples within a single assay, with an intra-assay CV of $9.6 \%$. Analytical sensitivity of this assay is $9 \mathrm{pg} / \mathrm{ml}$. Serum corticosterone concentrations were determined without diluting the sera, by immunoassay (R\&D Systems Inc., Minneapolis, USA), in duplicate samples within a single assay, with an intra-assay $\mathrm{CV}$ of $8.0 \%$. The sensitivity of this Corticosterone Immunoassay is typically less than $27 \mathrm{pg} / \mathrm{ml}$.

\section{Statistical analyses}

Morphometric and biochemical data obtained for the experimental groups were subjected to one-way analyses of variance (ANOVA). Duncan's multiple range test was used for post hoc comparisons between groups. The confidence level of $\mathrm{p}<0.05$ was considered statistically significant. The data are presented as means $\pm \mathrm{SD}$.

\section{RESULTS}

\section{Body and pituitary weights}

Data for body weight, absolute and relative pituitary weights are summarized in Table I. A $10 \%$ decrease $(\mathrm{p}<0.05)$ of mean body weight was observed in the Orx group in comparison to the SO group (before surgery they were around the same). Orchidectomy and subsequent genistein treatment did not affect the absolute pituitary weight of the animals. The relative pituitary weight increased by $15 \%(\mathrm{p}<0.05)$ for the Orx group and $34 \%(\mathrm{p}<0.05)$ for the $\mathbf{O r} \mathbf{x}+\mathbf{G}$ group in comparison with $\mathbf{S O}$ group.

\section{Immunohistochemical findings}

The ACTH-immunopositive cells were mostly located in the central part of the pituitary pars distalis. In SO middle-aged males they were often present as small groups in close proximity to numerous capillaries. ACTH-immunopositivity was granular, uniformly distributed throughout the relatively small portion of cytoplasm 
surrounding the prominent nuclei. Corticotrophs were ellipsoid or polygonal in shape, often with expressed cytoplasmatic projections (Fig 1).

In comparison to the SO controls, the ACTH-immunopositive cells in Orx rats were less numerous, darker and smaller, although their location and shape remained as in the controls (Fig 2). After genistein treatment, ACTH cells appeared smaller and darker than in both Orx and SO rats. Their shape was highly irregular (Fig 3).

\section{Morphometric findings}

Morphometric analyses showed that the corticotrophs in the control SO group had a mean cell volume of $912.1{\mu \mathrm{m}^{3}}^{3}$, a nuclear volume of $115.3 \mu^{3}$ and they occupied 20 $\%$ of the pituitary volume (Fig $4 a-c)$.

After orchidectomy, the cell volume and the relative cell volume (relative volume density) were significantly decreased by about $11 \%$ and $16 \%$, respectively $(\mathrm{p}<0.05$; Fig 4 a,c) compared to the SO group.

In $\mathbf{O r} \mathbf{x}+\mathbf{G}$ rats the cell volume of pituitary corticotrophic cells was smaller than in the Orx group by about $16 \%$ $(p<0.05$; Fig $4 a)$ and the relative volume density had decreased by $19 \%(\mathrm{p}<0.05$; Fig $4 \mathrm{c})$. Compared to the SO group, Vc had decreased by about 25\% (p<0.05; Fig 4a) and $\mathrm{V}_{\mathrm{VC}}$ by about $32 \%(\mathrm{p}<0.05$; Fig $4 \mathrm{c})$.

\section{Plasma ACTH and serum corticosterone levels}

The mean plasma levels of ACTH and serum levels of corticosterone are summarized in Figure 5 a-b. Orchidectomy did not affect these hormones, but in the Orx+G group both ACTH and corticosterone concentrations were reduced by about $23 \%$ and $31 \%$, respectively $(\mathrm{p}<0.05$; Fig $5 \mathrm{a}, \mathrm{b})$ in comparison with the vehicle-treated Orx group and the SO group (by about $12 \%$ and $34 \%$, respectively; $\mathrm{p}<0.05$; Fig 5 a,b).

\section{DISCUSSION}

The effects of subcutaneous treatment with genistein on the morphology and function of pituitary ACTH cells and circulating corticosterone levels were studied in the andropause, mimicked by using orchidectomized middle-aged male rats.

Orchidectomy was also performed to avoid any confounding effects on the HPA axis of endogenous sex steroids, of which the testes are the major source. This is an established approach for examining the potential effects of sex hormone-like compounds on hormonal homeostasis. The dose of genistein employed (30 mg/kg b.w.) was chosen to mimic human exposure to elevated concentrations of isoflavones when nutritional supplements are used for therapeutic purposes (Doerge and Sheehan, 2002). Some new data (Jefferson et al., 2007) suggest that subcutaneous treatment is legitimate, considering that totality of the injected genistein enters the circulation (about $80 \%$ is absorbed into blood when orally applied), so biological effects caused by either oral or subcutaneous application are very similar.

TABLE I

Body and pituitary weights in sham-operated (SO), orchidectomized (Orx) and genisteintreated orchidectomized $(\mathbf{O r x}+\mathbf{G})$ middle-aged male rats

\begin{tabular}{lccccc}
\hline $\begin{array}{l}\text { Experimental } \\
\text { group }\end{array}$ & $\begin{array}{c}\text { Initial body } \\
\text { weight (before } \\
\text { surgery }(\mathrm{g})\end{array}$ & $\begin{array}{c}\text { Body weight } \\
\text { before the } \\
\text { treatment }(\mathrm{g})\end{array}$ & $\begin{array}{c}\text { Body weigh } \\
\text { after the } \\
\text { treatment }(\mathrm{g})\end{array}$ & $\begin{array}{c}\text { Absolute } \\
\text { pituitary } \\
\text { weight }(\mathrm{mg})\end{array}$ & $\begin{array}{c}\text { Relative pituitary } \\
\text { weight }(\mathrm{mg} / 100 \mathrm{~g} \\
\text { body weight) }\end{array}$ \\
\hline SO & $680 \pm 30$ & $654 \pm 8$ & $650 \pm 29$ & $17.0 \pm 1.7$ & $2.20 \pm 0.14$ \\
Orx & $639 \pm 63$ & $586 \pm 35^{\mathrm{a}}$ & $16.6 \pm 1.4$ & $2.53 \pm 0.23^{\mathrm{a}}$ \\
Orx+G & $639 \pm 63$ & $632 \pm 57$ & $19.0 \pm 1$ & $2.96 \pm 0.20^{\mathrm{a}}$ \\
\hline
\end{tabular}

Mean $\pm \mathrm{SD}, \mathrm{n}=8$

${ }^{\mathrm{a}} \mathrm{p}<0.05$ vs. sham operated $(\mathbf{S O})$ rats 


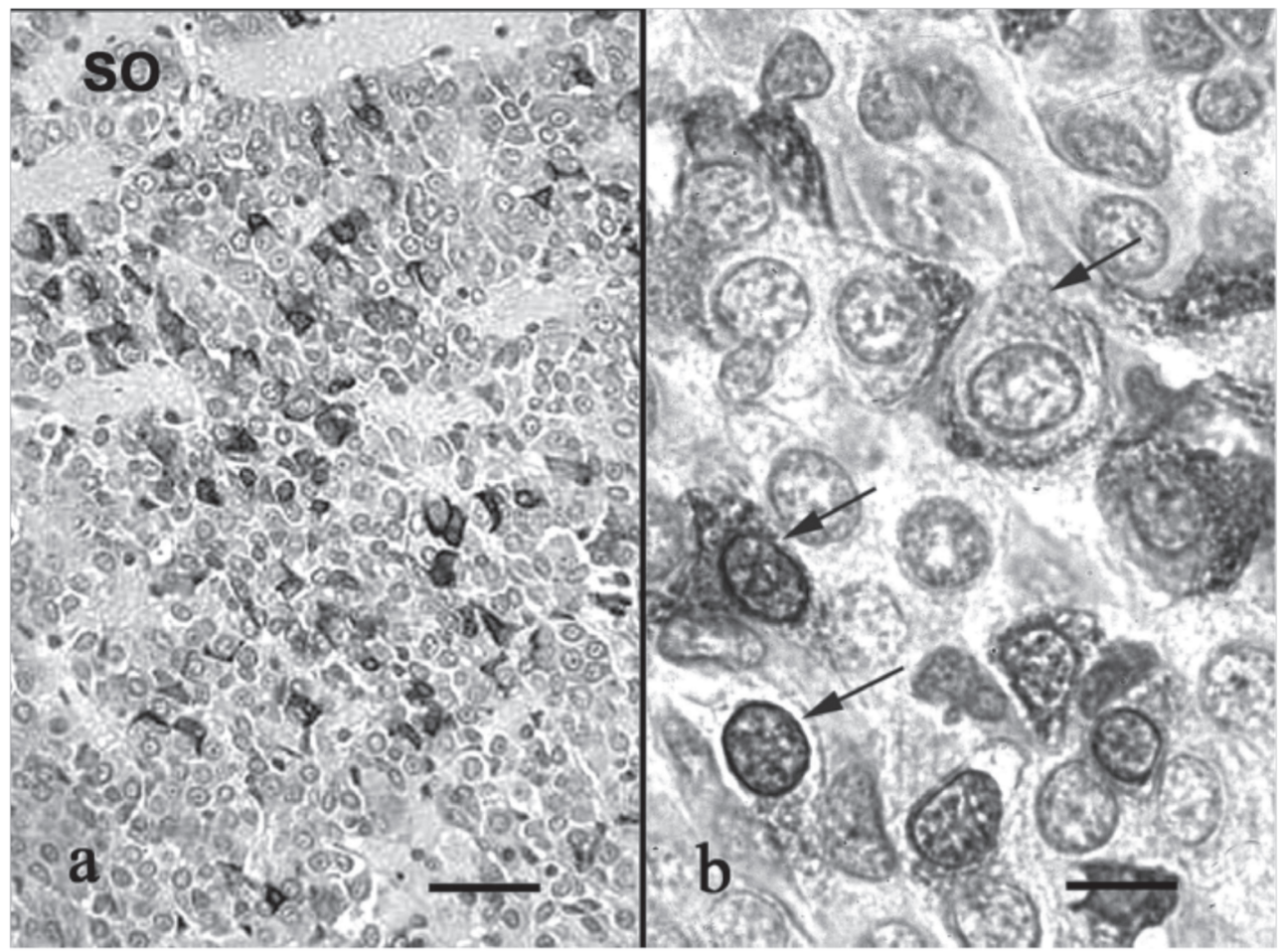

Figure 1a: Immunoreactive ACTH cells in the pars distalis of the pituitary gland from a control sham operated rat $(\mathbf{S O})$, PAP, bar $=40 \mu \mathrm{m}, \mathbf{1 b}$. higher magnification, bar $=8 \mu \mathrm{m}$

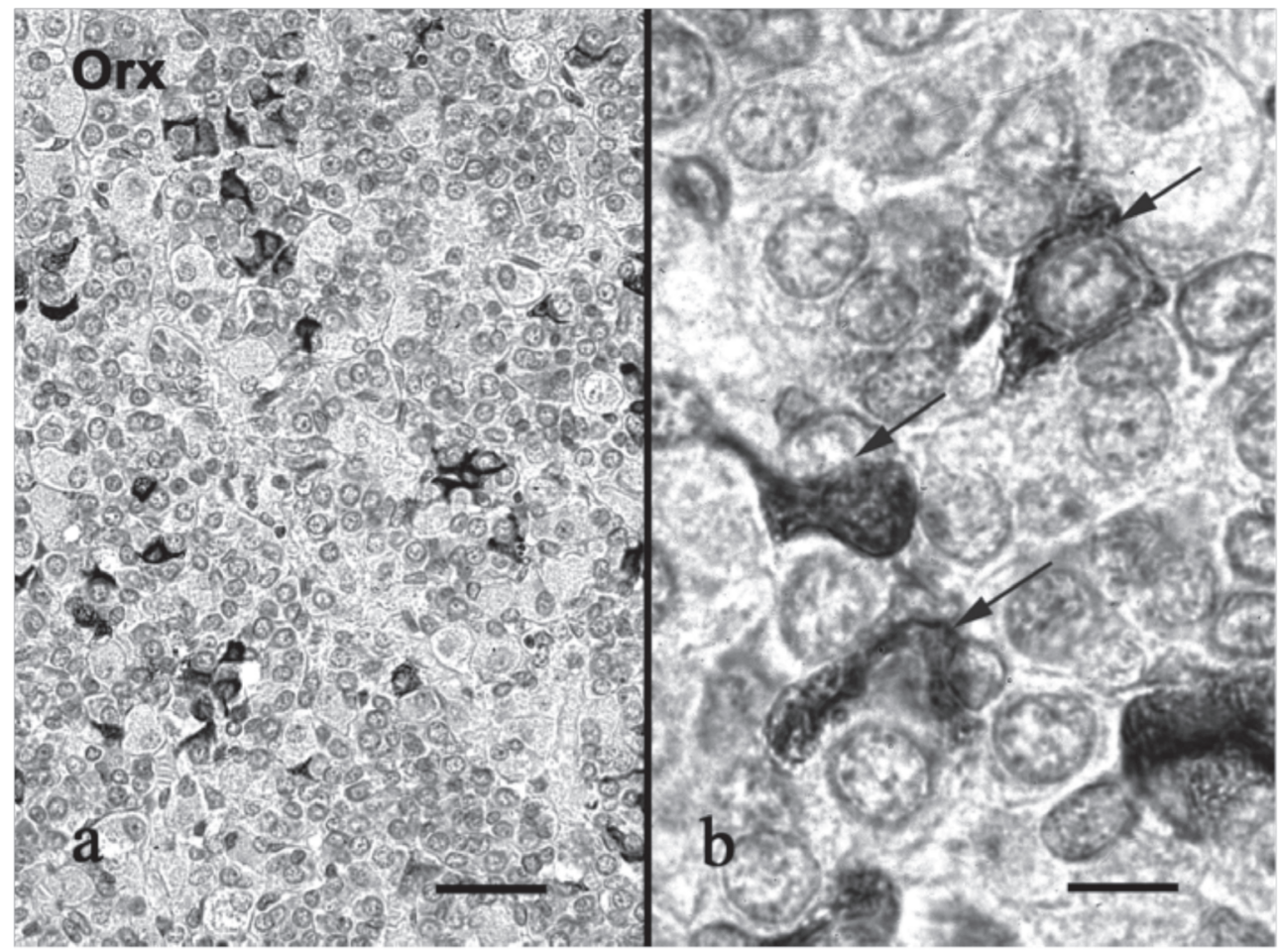

Figure 2a: Less numerous and smaller ACTH cells from an orchidectomized rats (Orx), PAP, bar $=40 \mu \mathrm{m}, \mathbf{2 b}$. higher magnification, bar $8=\mu \mathrm{m}$ 


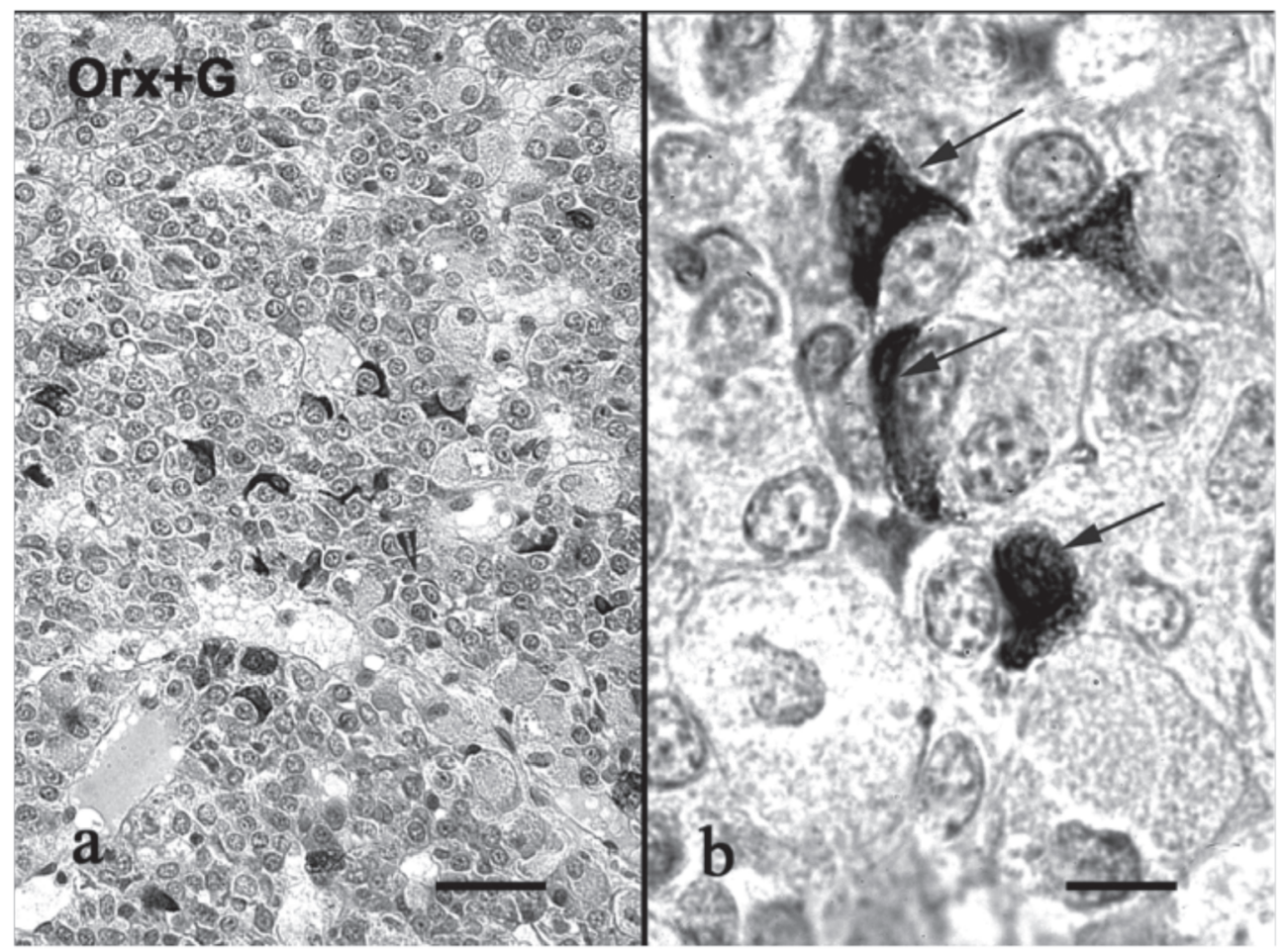

Figure 3a: Small, sparse ACTH cells in an orchidectomized and genistein treated rats (Orx+G), PAP, bar $=40 \mu \mathrm{m}, \mathbf{3 b}$. higher magnification, bar $=8 \mu \mathrm{m}$

To that end, using an injection strategy, we have operated with the form of soybean isoflavone available after digestive transformation (orally consumed soybean based therapeuticals contain genistin being hydrolyzed to nonconjugated active form genistein, due to digestive enzymes). The injection strategy was, also, used with a view to easily control the applied dose.

Under our experimental conditions, a significant decrease of mean body weight was detected five weeks after orchidectomy. This is in accordance with previous reports (Malendowicz, 1976) and may be due to atrophy of skeletal muscles induced by testosterone deprivation (Antonio et al., 1999). Subcutaneous genistein treatment of orchidectomized rats did not affect body weight in our animals. The reported effects of genistein on body weight in males are contradictory, as decreased (McClain et al., 2006), increased (Penza et al., 2006) or, as in our study, no effect on body weight (Faqi et al., 2004) has been recorded, probably due to different treatment protocols and experimental conditions.

Orchidectomy and subsequent genistein treatment increased the relative pituitary weight when compared to SO rats. At least for Orx rats this is probably the consequence of decreased body weight, since no significant changes in absolute pituitary weights were detected. However, the detected increase of relative pituitary weight was higher in the Orx+G group and may be partly the result of an estrogenic effect of genistein on pituitary estrogen-responsive cells, namely prolactin cells. Consistent with these results was the trend towards increased relative pituitary weight in both male and female pups whose dams had received high doses of genistein (Delclos et al., 2001). On the other hand, it was shown that genistein facilitated the development of an estrogen responsive pituitary tumor cell line transplanted into rats (Fujimoto and Honda, 2003). Further examinations of pituitary prolactin cells in our experimental model are needed to confirm this hypothesis. 
The immunohistochemical and morphometric analyses revealed a decreased volume and the relative volume density of ACTH cells without an accompanying decrease in plasma level of ACTH after orchidectomy of middle-aged rats. It was reported that orchidectomy causes persistent CRH release (Bingaman et al., 1994). The data of the cell number and total volume of the ACTH cells should help to brighten depict the morphofunctional changes after orchidectomy. On the other hand, $13 \%$ of plurihormonal cells, which contained both ACTH and gonadotropic hormones, were detected within the population of rat pituitary corticotropes (Childs et al., 1982). Therefore, it is possible to postulate the hypothesis (which, naturally, needs verification by using some advanced microscopy techniques), that the transdifferentiation of the multi-hormonal ACTH cells to gonadotropes, caused by orchidectomy, provokes the changes in the population of pituitary corticotropes.
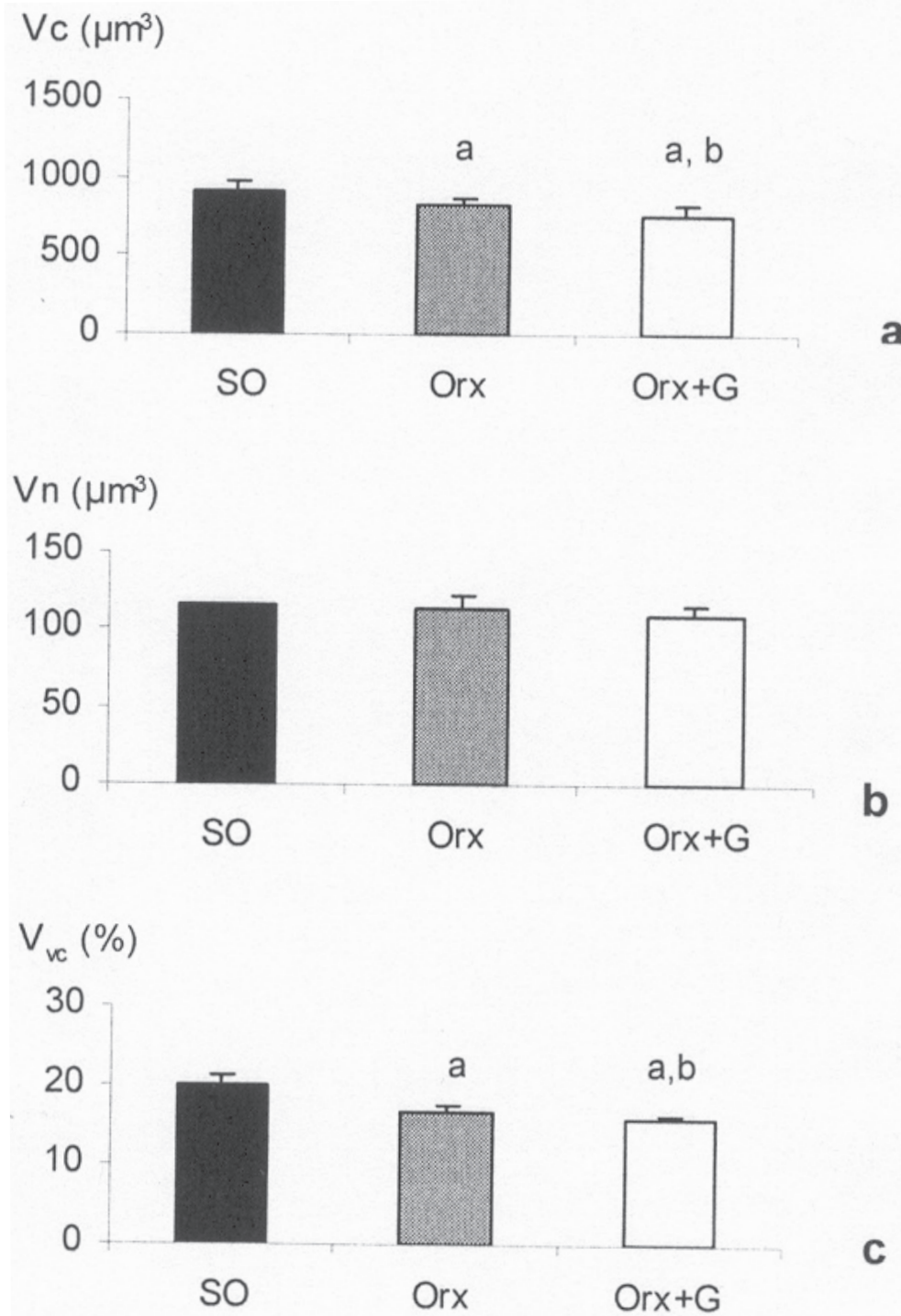

Figure 4a: Cellular volume $\left(\mathrm{Vc} ; \mu \mathrm{m}^{3}\right)$ of ACTH cells; b. nuclear volume $\left(\mathrm{Vn} ; \mu^{3}\right)$ of ACTH cells; c. relative volume density $\left(\mathrm{V}_{\mathrm{VC}} ; \%\right)$ of $\mathrm{ACTH}$ cells expressed as percentages of total gland tissue; All values are the means \pm standard deviation, $n=8$ animals per group, ${ }^{a} p<0.05$ vs. sham operated (SO), ${ }^{\mathrm{b}} \mathrm{p}<0.05$ vs. orchidectomized (Orx) 

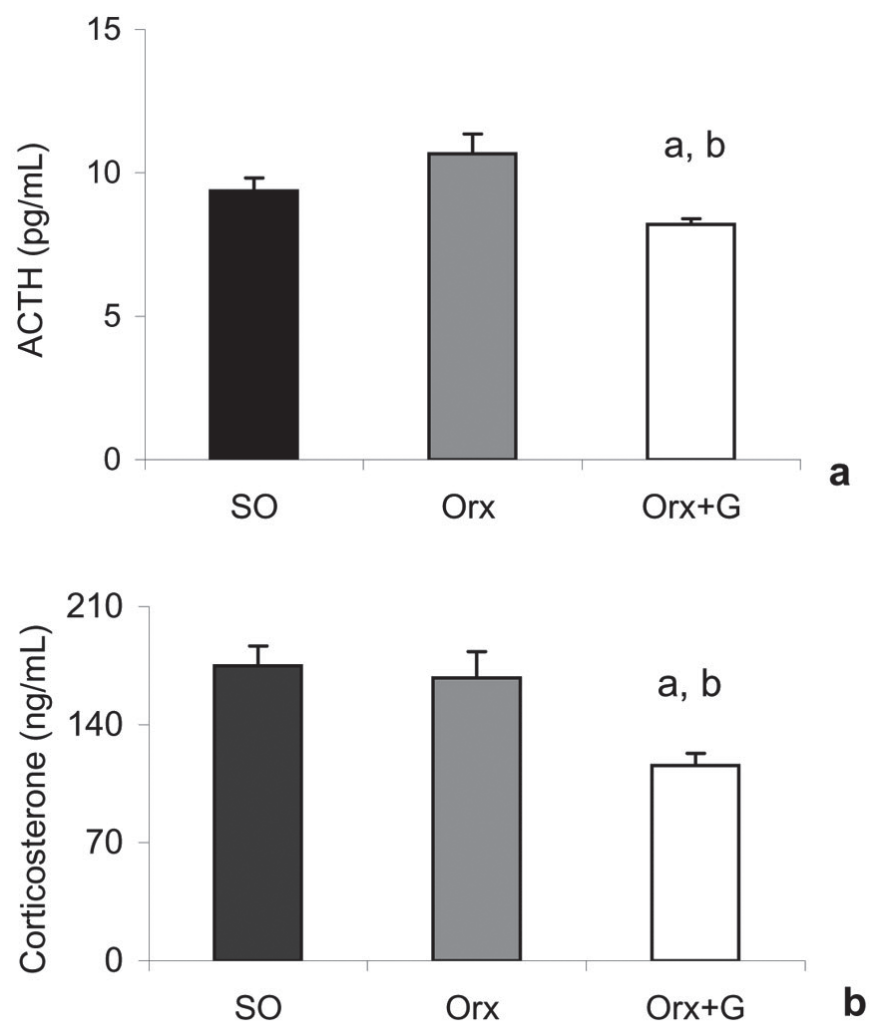

Figure 5a: Plasma concentration of ACTH; b. serum concentration of corticosterone, in middle aged male rats. The values are the means \pm standard deviation, $n=8$ animals per group, ${ }^{a} \mathrm{p}<0.05$ vs. sham operated (SO), ${ }^{\mathrm{b}} \mathrm{p}<0.05$ vs. orchidectomized (Orx).

In this study we demonstrated that high doses of genistein inhibited the HPA axis. Decreased immunohistomorphometric features of pituitary ACTH cells and reduced circulating $\mathrm{ACTH}$ and corticosterone levels were clearly evident in the Orx+G group when compared to both the Orx and SO groups. It was reported that estrogen replacement lowered the POMC mRNA level and the ACTH response to repeated stressful stimuli in ovariectomized rats (Redei et al., 1994). Besides the estrogenic mechanism, genistein may also reduce the level of $\mathrm{ACTH}$ through inhibition of tyrosine kinase phosphorylation cascades (Katahira et al., 1998). Various cytokines are generated during stress and regulate the HPA axis. Thus, IL-1 was shown to increase POMC mRNA concentrations in vivo (Harbuz et al., 1992) and in vitro in a primary culture of rat anterior pituitary cells (Suda et al., 1989); IL-2 stimulated ACTH secretion and/or POMC expression in vivo (Harbuz and Lightman, 1989; Naito et al., 1989; Hanisch et al., 1994) and in vitro (Karanth and McCann, 1991); IL-6 stimulated ACTH secretion at the level of both the hypothalamus and pituitary (Matta et al., 1992). As phosphorylation cascades represent the central signaling pathway for several cytokines and since they operate in ACTH cells, genistein, a broad spectrum inhibitor of protein tyrosine kinase and several other kinases, was proposed to act on ACTH cells by this mechanism (Katahira et al., 1998). Considering that our experimental animals suffered stressful stimuli (orchidectomy, subcutaneous treatment), we expect that effects of genistein were investigated under the conditions of increased cytokine generation, so decreased plasma ACTH after genistein treatment may be a result of indicated mechanism, as well. Considering that the controls were on equal stressful terms 
(levels of ACTH were around $10 \mathrm{pg} / \mathrm{ml}$ ) the genistein action is distinctive.

It seems logical to assume that, under our experimental conditions, genistein treatment reduced serum corticosterone through central effects, by lowering pituitary ACTH release. However, a direct action of genistein on the adrenal cortex cannot be disregarded. Geńistein was shown to suppress cortisol secretion in the human adrenocortićal cell line, H925, and the porcine adrenocortical cells (Mesiano et al., 1999; Kaminska et al., 2007). It was shown that subcutaneous administration of genistein at $3 \mathrm{nmol} / 100 \mathrm{~g}$ significantly lowered the blood corticosterone level in ovariectomized rats unrelated to its estrogen-like activity (Malendowicz et al., 2006). On the other hand, it was reported that genistein in vitro strongly inhibited human adrenocortical $3 \beta$-hydroxysteroid dehydrogenase (Ohno et al., 2002), similar to estrogen action (Rao and Chinoy, 1986), and reduced the activity of 21-hydroxylase (P450c21), the latter finding also confirmed (Mesiano et al., 1999).

After continuous administration of genistein to weanling rats, expansion of cells at zona fasciculata and zona reticularis of the adrenal cortex was reported, accompanied by decreased corticosterone and elevated ACTH concentrations in blood (Ohno et al., 2003). Contrary to our conclusions, the authors considered the increase in serum ACTH concentration to be the result of a feedback effect of genistein-induced decline in adrenal production of corticosterone. It is well-known that in developing rodents there is a short period (from $4^{\text {th }}$ to $14^{\text {th }}$ postnatal day) when central regulation of the adrenal response to stress is either minimal or nonexistent, a stress hyporesponsive period. Therefore, the discrepancy between these results and ours are probably due to the different age of the experimental animals.

In conclusion, this study showed that subcutaneous genistein administration modulated immunohistomorphometric features of pituitary ACTH cells and altered the HPA axis by decreasing both ACTH and corticosterone levels in orchidectomized middle-aged rats.

\section{ACKNOWLEDGMENTS}

Thanks are due to Mr. Granic (Promedia, Zrenjanin, Serbia) for a donation and to Ivanka Milenkovic (Olympus, Belgrade, Serbia) for taking the digital photos. This work was supported by the Ministry for Science of Serbia, Grant number 143007B.

\section{REFERENCES}

AKIYAMA T, ISHIDA J, NAKAGAWA S, OGAWARA H, WATANABE S, ITOH N, SHIBUYA M, FUKAMI Y (1987) Genistein, a specific inhibitor of tyrosinespecific protein kinases. J Biol Chem 262: 5592-5595

ANTONIO J, WILSON JD, GEORGE FW (1999) Effects of castration and androgen treatment on androgenreceptor levels in rat skeletal muscles. J Appl Physiol 87: 2016-2019

BATEMAN A, SINGH A, KRAL T, SOLOMON S (1989) The immune hypothalamic-pituitary-adrenal axis. Endocr Rew 10: 92-112

BENASSAYAG C, PERROT-APPLANAT M, FERRE $F$ (2002) Phytoestrogens as modulators of steroid action in target cells. J Chromatogr B 777: 233-248

BESEDOVSKY HO, DEL REY A (1996) Immune-neuroendocrine interactions: facts and hypothesis. Endocr Rew 17: 64-102

BINGAMAN EW, MAGNUSON DJ, GRAY TS, HANDA RJ (1994) Androgen inhibits the increases in hypothalamic corticotropin-releasing hormone $(\mathrm{CRH})$ and $\mathrm{CRH}$-immunoreactivity following gonadectomy. Neuroendocrinology 59: 228-234

BREVINI TA, ZANETTO SB, CILLO F (2005) Effects of endocrine disruptors on developmental and reproduction functions. Curr Drug Targets Immune Endocr Metabol Disord 5: 1-10

CASERTA D, MARANGHI L, MANTOVANI A, MARCI R, MARANGHI F, MOSCARINI M (2008) Impact of endocrine disruptor chemicals in gynaecology. Hum Reprod Update 14: 59-72

CHILDS GV, ELLISON DG, FOSTER L, RAMALEY JA (1982) Adrenocorticotropin storge in corticotropes and a subpopulation of gonadotropes during the stress nonresponsive period in the neonatal male rat. Endocrinology 110: 1676-1692

DELCLOS KB, BUCCI TJ, LOMAX LG, LATENDRESSE JR, WARBRITTON A, WEIS CC, NEWBOLD RR (2001) Effects of dietary genistein exposure during development on male and female CD (SpragueDawley) rats. Reprod Toxicol 15: 647-663

DOERGE D, SHEEHAN D (2002) Goitrogenic and estrogenic activity of soy isoflavones. Environ Health Perspect 110: 349-353

FAQI AS, JOHNSON WD, MORRISEY RL, MCCORMICK DL (2004) Reproductive toxicity assessment of chronic dietary exposure to soy isoflavones in male rats. Reprod Toxicol 18: 605-611

FUJIMOTO N, HONDA H (2003) Effects of environmental estrogenic compounds on growth of a transplanted estrogen responsive pituitary tumor cell line in rats. Food Chem Toxicol 41: 1711-1717

HANISCH UK, ROWE W, SHARMA S, MEANEY MJ, QUIRION R (1994) Hypothalamic-pituitary-adrenal activity during chronic central administration of interleukin-2. Endocrinology 135: 2465-2472 
HARBUZ MS, LIGHTMAN SL (1989) Responses of hypothalamic and pituitary mRNA to physical and phychological stress in the rat. J Endocrinol 122: 705-711

HARBUZ MS, STEPHANOU A, SARLIS N, LIGHTMAN SL (1992) The effects of recombinant human interleukin (IL)- $1 \alpha$, IL-1 $\beta$ or IL- 6 on hypothalamopituitary-adrenal axis activation. J Endocrinol 133: 349-355

HATZINGER M, WOTJAK CT, NARUO T, SIMCHEN R, KECK ME, LANGRAF R, HOLSBOER F, NEUMAN ID (2000) Endogenous vasopressin contributes to hypothalamic-pituitary-adrenocortical alterations in aged rats. J Endocr 164: 197-205

JEFFERSON WN, PADILLA-BANKS E, NEWBOLD RR (2007) Disruption of the female reproductive system by the phytoestrogen genistein. Rep Tox 23: 308-316

KAMINSKA B, OPALKA M, DUSZA L (2007) Phytoestrogens alter cortisol and androstenedione secretion by porcine adrenocortical cells. Acta Vet Hung 55: 359-367

KARANTH S, MCCANN SM (1991) Anterior pituitary hormone control by interleukin 2. Proc Natl Acad Sci USA 88: 2961-2965

KATAHIRA M, IWASAKI Y, AOKI Y, OISO Y, SAITO $\mathrm{H}$ (1998) Cytokine regulation of the rat proopiomelanocortin gene expression in AtT-20 cells. Endocrinology 139: 2414-2422

KUIPER GG, CARLSSON B, GRANDIEN K, ENMARK E, HAGGBLAD J, NILSSON S, GUSTAFSSON JA (1997) Comparison of the ligand binding specificity and transcript tissue distribution of estrogen receptors alpha and beta. Endocrinology 138: 863-870

LAMBERTS SW, VAN DEN BELD AW, VAN DER LELY AJ (1997) The endocrinology of ageing. Science 278: 419-424

MALENDIWICZ LK (1974) Sex differences in adrenocortical structure and function I. The effects of postpubertal gonadectomy and gonadal hormone replacement in nuclear volume of adrenocortical cells in the rat. Tissue Res 151: 525-536

MALENDOWICZ LK (1976) Sex differences in adrenocortical structure and function III. The effects of postpubertal gonadectomy and gonadal hormone replacement on adrenal cholesterol sidechain cleavage activity and on steroids biosynthesis by rat adrenal homogenates. Endokrinologie 67: 26-35

MALENDOWICZ LK, TREJTER M, REBUFFAT P, ZIOLKOWSKA A, NUSSDORFER GG, MAJCHRZAK $M$ (2006) Effects of some endocrine disruptors on the secretory and proliferative activity of the regenerating rat adrenal cortex. Int J Mol Med 18: 197-200

MATTA SG, WEATHERBEE J, SHARP BM (1992) A central mechanism is involved in the secretion of ACTH in response to IL-6 in rats: comparison to and interaction with IL-1 $\beta$. Neuroendocrinology 56: 516-525

MCCLAIN RM, WOLZ E, DAVIDOVICH A, PFANUKUCH F, EDWARDS JA, BAUSCH J (2006) Acute, subchronic and chronic safety studies with genistein in rats. Food Chem Toxicol 44: 56-80

MESIANO S, KATZ SL, LEE JY, JAFFE RB (1999) Phytoestrogens alter adrenocortical function: genistein and daidzein suppress glucocorticoid and stimulate androgen production by cultured adrenal cortical cells. J Clin Endocrinol Metab 84: 2443-2448

NAITO Y, FUKATA J, TOMINAGA T, MASUI Y, HIRAI Y, MURAKAMI N, TAMAI S, MORI K, IMURA H (1989) Adrenocorticotropic hormone-releasing activities of interleukins in a homologous in vivo system. Biochem Biophys Res Commun 164: 12621267
OHNO S, SHINODA S, TOYOSHIMA S, NAKAZAWA H, MAKINO T, NAKAJIN S (2002) Effects of flavonoid phytochemicals on cortisol production and on activities of steroidogenic enzymes in human adrenocortical H295R cells. J Steroid Biochem Mol Biol 80 : 355-363

OHNO S, NAKAJIMA Y, INOUE K, NAKAZAWA H, NAKAJIN S (2003) Genistein administration decreases serum corticosterone and testosterone levels in rats. Life Sci 74: 733-742

PENZA M, MONTANI C, ROMANI A, VIGNOLINI P, PAMPALONI B, TANINI A, BRANDI ML, ALONSOMAGDALENA P, NADAL A, OTTOBRINI L, PAROLINI O, BIGNOTTI E, CALZA S, MAGI A, GRIGOLATO PG, DI LORENZO D (2006) Genistein affects adipose tissue deposition in a dose-dependent and gender-specific manner. Endocrinology 147: 57405751

PHILLIPS KP, TANPHAICHITR N (2008) Human exposure to endocrine disrupters and semen quality. J Toxicol Environ Health B Crit Rev 11. 188- 220

PICHERIT C, COXAM V, BENNETAU-PELISSERO C, KATI-COULIBALY S, DAVICCO MJ, LEBECQUE P, BARLET JP (2000) Daidzein is more efficient than genistein in preventing ovariectomy-induced bone loss in rats. J Nutr 130: 1675-1681

PRICE KR, FENWICK GR (1985) Naturally occurring oestrogens in foods-a review. Food Addit Contam 2 : 73-106

RAFFOUL JJ, WANG Y, KUCUK O, FORMAN JD, SARKAR FH, HILLMAN GG (2006) Genistein inhibits radiation-induced activation of NF-kappaB in prostate cancer cells promoting apoptosis and $\mathrm{G} 2 / \mathrm{M}$ cell cycle arrest. BMC cancer 6: 107

RAMOS S (2007) Effects of dietary flavonoids on apoptotic pathways related to cancer chemoprevention. J Nutr Biochem 18: 427-442

RAO MV, CHINOY NJ (1986) Effect of estradiol benzoate on rat testis and adrenal. Exp Clin Endocrinol 88: 181184

REDEI E, LI L, HALASZ I, MCGIVERN RF, AIRD F (1994) Fast glucocorticoid feedback inhibition of ACTH secretion in the ovariectomized rat: effect of chronic estrogen and progesterone. Neuroendocrinology 60: 113-123

SETCHELL KDR (1998) Phytoestrogens: the biochemistry, physiology, and implications for human health of soy isoflavones-a review. Am J Clin Nutr 68: 1333S-46S

STARCEVIC V, MILOSEVIC V, BRKIC B, SEVERS WB (2000) Effects of centrally applied somatostatin on pituitary adrenocorticotropes in female rats. Pharmacology 60: 203-207

STERNBERGER LA, HARDY PHJ, CUCULIUS JJ, MEYER HG (1970) The unlabelled antibody enzyme method of immunohistochemistry. Preparation and properties of soluble antigen-antibody complex (horseradish peroxidase-antihorseradish peroxidase) and its use in identification of spirochetes. J Histochem Cytochem 18: 315-333

SUDA T, TOZAWA F, USHIYAMA T, TOMORI N, SUMITOMO T, NAKAGAMI Y, YAMADA M, DEMURA H, SHIZUME K (1989) Effects of protein kinase-C-related adrenocorticotropin secretagogues and interleukin-1 on proopiomelanocortin gene expression in rat anterior pituitary cells. Endocrinology 124: 14441449

VANCE ML (2003) Andropause. GH \& IGF Research 13: S90-S92

WEIBEL ER (1979) Stereological Methods 1. Practical Methods for Biological Morphometry. Academic Press, London. 